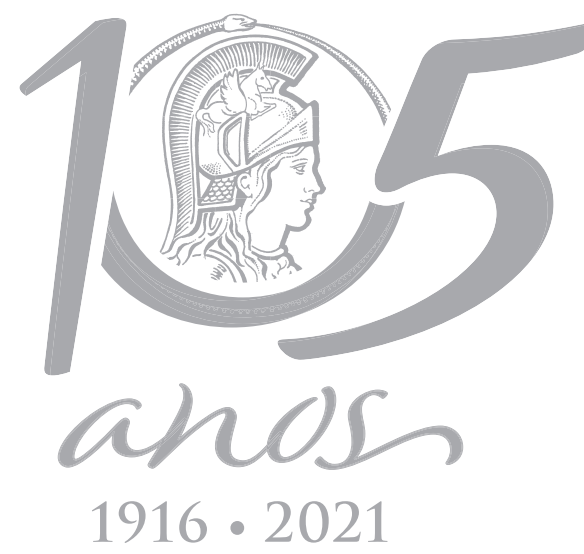

\title{
Brazilian peppertree, eucalyptus, and velame honeys: does palynology confirm the predominant flower sources indicated by beekeepers?
}

\author{
MICHELE S.F. BANDEIRA \& JAÍLSON S. NOVAIS
}

\begin{abstract}
We investigated ten honey samples from the Discovery Coast of Bahia, Brazil, to confirm the three predominant flower sources indicated by regional beekeepers: Brazilian peppertree - Schinus terebinthifolia Raddi; eucalyptus - Eucalyptus L'Hér. spp.; and velame - Croton L. spp.. The honeys were collected in five Southern Bahia municipalities - Belmonte, Eunápolis, Guaratinga, Itabela and Porto Seguro. The samples underwent acetolysis and, after slides mounting, the pollen types were identified and counted to determine the frequency classes. The pollen spectra revealed 31 pollen types in 27 genera and 17 families. The palynological analysis confirmed the predominant eucalyptus flower source indicated for four honey samples from Belmonte, Eunápolis, Itabela and Porto Seguro. Three honey samples previously indicated with predominant eucalyptus and velame flower sources had no predominant pollen. Eucalyptus predominated as the main flower source for another three samples previously indicated by beekeepers as Brazilian peppertree and velame. We conclude that regional honeys marketed as having a predominant flower source may have distinct botanical origin. This demands further research aimed at reviewing which bee plants provide resources for monofloral, bifloral and plurifloral honeys in the Bahian Discovery Coast.
\end{abstract}

Key words: Apis mellifera, Atlantic Rain Forest, melissopalynology, monofloral honey, pollen analysis, unifloral honey.

\section{INTRODUCTION}

Among the consequences caused by the loss of Atlantic Rain Forest areas in Brazil (SOS Mata Atlântica Foundation 2017) is the deficit in ecosystem services, such as pollination, an essential process for the reproduction of most plant species (Varassin et al. 2021). Furthermore, deforestation affects the flora available for bees and other animals that depend on plants for food, shelter, defense, etc. Knowing the beeexploited flora is essential to plan strategies for biodiversity conservation, and pollen analysis proves to be an effective method employed for this purpose. Also, pollen identification can indicate the geographical and botanical origin of bee products, such as honey, bee pollen, and propolis, since the pollen types found in these products equate to "fingerprints" of bee foraging habits (Jones \& Bryant 1996).

Palynological studies subsidize honey classification based on the pollen spectrum. Monofloral or unifloral honeys include above $45 \%$ of pollen grains from a single plant species (Louveaux et al. 1978). On the other hand, a multifloral honey sample has no predominant pollen (Ricciardelli-D'Albore 1997). Monofloral honeys are appreciated by consumers due to their flavor, color, aroma, and pharmacological 
properties. These honeys have higher prices on both the domestic and foreign market (Andrade et al. 1999) and, therefore, have higher added value. This requires that the information printed on labels or indicated by sellers be verified, in order to know whether such honeys actually meet the criteria necessary to be classified as monofloral. However, classifying the samples as monofloral honeys due to a pollen type with frequency exceeding $45 \%$ in the pollen spectrum can lead to misinterpretation, as consumers tend to believe that honey comes from a single floral source. This occurs if we disregard aspects of the floral biology of the plant species associated with the pollen types, as well as the floral diversity of each region. Moreover, "no honey produced by bees flying free is likely to be entirely unifloral" (Molan 1998, p. 79). Therefore, the term "honey from predominant flower sources" seems to be more appropriate than "monofloral honey" for most of the Brazilian honeys.

Pollen grains in monofloral or predominant flower source honeys have been examined by a variety of studies abroad, such as in Algeria (Makhloufi et al. 2015), Argentina (Ciappini et al. 2016, Sánches \& Lupo 2017), Austrália (Seijo et al. 2003, Sniderman et al. 2018), Portugual (Seijo et al. 2003), Ethiopia (Belay et al. 2017), Spain (Seijo et al. 2003, 2015). In Brazil, monofloral indicated honeys were palynologically analyzed by Barth (1990), in São Paulo, Maranhão, and Mato Grosso do Sul, Almeida-Muradian et al. (2014) in Ceará, Borges et al. (2014) in Piauí, and Kadri et al. (2016) in Espírito Santo States. However, research on predominant flower source or monofloral honeys in Bahia is lacking.

In southern Bahia, municipalities such as Eunápolis and Guaratinga stand out for their honey production (IBGE 2016), contributing to the Bahian performance in the national production scenario. Predominant flower source or monofloral indicated honeys are commercialized either at regional fairs or directly from producers. This assumed predominant botanical origin still relies on the beekeeper's empirical observations around the apiary. In order to improve this information, palynological analysis can indicate the botanical origin of honeys more accurately, subsidizing regional beekeeping.

In a previous work (Bandeira \& Novais 2020), we presented the pollen spectra of 21 honey samples from the Discovery Coast of Bahia. Our current study complements the questions addressed in the previous manuscript by analyzing 10 regional honey samples indicated by beekeepers as coming from three predominant flower sources - Brazilian peppertree (Schinus terebinthifolia Raddi), eucalyptus (Eucalyptus L'Hér. spp.) and velame (Croton L. spp.), the main so-called monofloral honeys produced in the study region. We hypothesize that palynological analysis will reveal a multifloral origin for the Discovery Coast's honeys, due to the diversity of regional flora.

\section{MATERIALS AND METHODS}

\section{Study site}

The study was carried out in five municipalities along the Discovery Coast in the state of Bahia: Belmonte (BL), Eunápolis (EU), Guaratinga (GU), Itabela (IT), and Porto Seguro (PS). Ten samples of Apis mellifera L. 1758 (Hymenoptera: Apidae: Apinae) honey indicated to be from predominant flower sources were obtained from local beekeepers (Table I), between November 2017 and August 2018. In general, beekeepers base this indication on empirical observation of flowering plants in the surroundings of apiaries. This vegetation encompasses backyard areas, monocultures of banana, coffee, eucalyptus, pumpkin and pastures (Bandeira \& Novais 2019). 
Table I. Municipalities of the Discovery Coast (Bahia, NE Brazil), honey sample codes, geographical coordinates of the apiaries, and predominant flower sources indicated by the beekeepers for each honey sample.

\begin{tabular}{|c|c|}
\hline $\begin{array}{l}\text { Municipalities, honey sample codes and } \\
\text { geographical coordinates }\end{array}$ & Predominant flower source indicated by beekeepers \\
\hline \multicolumn{2}{|l|}{ Belmonte - BL } \\
\hline BL1 - 16@05.025' S; 39@14.974' W & eucalyptus (Eucalyptus L'Hér. spp., Myrtaceae) \\
\hline \multicolumn{2}{|l|}{ Eunápolis - EU } \\
\hline EU1 - 16@18.657' S; 39025.728' W & eucalyptus (Eucalyptus spp., Myrtaceae) \\
\hline $\begin{array}{c}\text { Guaratinga - GU } \\
\text { GU1 - 1629.128' S; 39055.926' W }\end{array}$ & eucalyptus (Eucalyptus spp., Myrtaceae) \\
\hline GU2 - 16029.042' S; 39055.836' W & velame (Croton L. spp., Euphorbiaceae) \\
\hline GU3 - 16029.128' S; 39055.926' W & velame (Croton spp., Euphorbiaceae) \\
\hline GU4, GU5 - 16029.128' S; 39055.926' W & velame (Croton spp., Euphorbiaceae) \\
\hline \multicolumn{2}{|l|}{ Itabela - IT } \\
\hline IT1 - 1621.423' S; 3937.430' W & eucalyptus (Eucalyptus spp., Myrtaceae) \\
\hline IT2 - 16021.423' S; 39037.430' W & $\begin{array}{l}\text { Brazilian peppertree (Schinus terebinthifolia Raddi, } \\
\text { Anacardiaceae) }\end{array}$ \\
\hline \multicolumn{2}{|l|}{ Porto Seguro - PS } \\
\hline 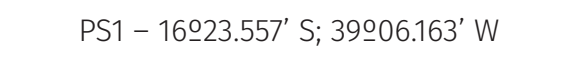 & eucalyptus (Eucalyptus spp., Myrtaceae) \\
\hline
\end{tabular}

\section{Sample processing}

All honey samples were prepared using the acetolysis technique (Erdtman 1960), including the initial dilution of 10 grams of honey in warm distilled water $\left( \pm 40^{\circ} \mathrm{C}\right)$ and ethyl alcohol (Jones \& Bryant 1996). At least four slides per sample were prepared, and the pollen sediment was mounted in glycerin gelatin for the microscopic analysis. The pollen slides are deposited in the pollen library at the Federal University of Southern Bahia - palinoFLORAS -, a pollen reference collection associated with the FLORAS Botanical Garden (Novais et al. 2018), based in Porto Seguro, Bahia.

\section{Palynological analysis}

The pollen types found on the honey sediment slides were botanically identified by comparison with the reference slides at palinoFLORAS, as well as through specialized literature, such as Roubik \& Moreno (1991), Silva et al. (2016), and Lorente et al. (2017). At least 500 pollen grains were counted per sample (Moar 1985). To classify the abundance of pollen grains in each sample, we adopted the frequency classes established by Louveaux et al. (1978): predominant pollen (>45\%), secondary pollen (16\%-45\%), important minor pollen (3\%-15\%), and minor pollen $(<3 \%)$. According to Ramalho et al. (1990), pollen sources exceeding $10 \%$ can be considered an attractive floral resource for bees. In this work, we classified 
honey samples as predominant flower sources if they presented predominant or secondary pollen types, except when these types were related to polliniferous or anemophilous plants. We avoid classifying honeys as monofloral, given the diverse flora of Southern Bahia, and to prevent misinterpretation.

\section{RESULTS}

\section{Pollen spectra of the honey samples}

We recognized the botanical affinity of 31 pollen types in the honey samples, distributed across 27 genera and 17 families (Table II). The Eucalyptus and Mimosa pudica pollen types occurred in most of the samples - except for Eucalyptus in GU5 and M. pudica in EU1 - and stood out in some honeys from Guaratinga (GU1, GU2 and GU4, M. pudica), Itabela and Porto Seguro (IT1, IT2 and PS1, Eucalyptus). No predominant pollen was found in the samples from Belmonte (BL1) and Eunápolis (EU1), nor in GU3 and GU5 samples from Guaratinga. Five pollen types were within the secondary pollen class: Cecropia, Eucalyptus, M. pudica, Myrcia 2 and Solanum 1.

\section{Honeys from predominant flower sources}

According to the beekeepers, eucalyptus (Eucalyptus spp., Myrtaceae) was the predominant flower source of the honey samples from Belmonte. We found no predominant pollen (>45\%) in that honey. However, the Eucalyptus (38.2\%) and Myrcia 2 (29.6\%) pollen types appeared as secondary pollen. The pollen types classified as important minor and minor pollen were Borreria verticillata, Cecropia, Cuphea flava, Desmodium, Euterpe, Mikania, Mimosa caesalpiniifolia, Mimosa pudica, Myrcia 1, Richardia, Simira, and Vernonia. The predominant flower source of Eucalyptus sp. (Myrtaceae) and Myrcia sp. (Myrtaceae) palynologically characterized the honey sample from Belmonte (Table II).

The honey sample from the municipality of Eunápolis had a predominant eucalyptus flower source previously indicated by the local beekeepers. However, no predominant pollen was found. Two pollen types were categorized as secondary pollen: Cecropia (16.8\%) and Eucalyptus (35.8\%). The Borreria verticillata, Bougainvilea, Brosimum, Desmodium, Mikania, Myrcia 1, Piper, and Vernonia pollen types were classified as important minor and minor pollen. Palynologically, Eucalyptus spp. (Myrtaceae) predominated as the main floral source for this honey sample, since Cecropia sp. (Urticaceae) is predominantly anemophilous (Table II).

Beekeepers have indicated that honeys from Guaratinga had two predominant flower sources: eucalyptus (Eucalyptus spp., Myrtaceae) for the sample GU1, and velame (Croton spp., Euphorbiaceae) for the samples GU2-GU5. The Mimosa pudica pollen type predominated in the samples GU1 (86.6\%), GU 2 (50\%), and GU4 (48,6\%). The samples GU3 and GU5 had no predominant pollen. The Eucalyptus pollen type was secondary for the samples GU2 (35.6\%) and GU4 (30.7\%), similar to the Mimosa pudica pollen type for GU3 (21.6\%) and GU5 (32\%), and to the Solanum 1 pollen type for GU3 (28.3\%) and GU5 (28.3\%). Therefore, the samples GU1, GU3 and GU5 had no predominant flower source palynologically indicated. The GU2 and GU4 honeys palynologically revealed a predominant eucalyptus (Eucalyptus sp., Myrtaceae) flower source, given the polliniferous characteristic of Mimosa pudica L. (Fabaceae) flowers (Table II).

The honey samples from Itabela had a predominant eucalyptus (Eucalyptus spp., Myrtaceae) (IT1) and Brazilian peppertree - locally known as aroeira - (Schinus terebinthifolia, Anacardiaceae) (IT2) flower source previously indicated by beekeepers. The 
Table II. Pollen spectrum recognized in honey samples of Apis mellifera L. from the municipalities along the Discovery Coast (Bahia, NE Brazil): Belmonte (BL), Eunápolis (EU), Guaratinga (GU), Itabela (IT) and Porto Seguro (PS). Frequency classes according to Louveaux et al. (1978).

\begin{tabular}{|c|c|c|c|c|c|}
\hline $\begin{array}{l}\text { Honey } \\
\text { sample code } \\
\text { and number } \\
\text { of pollen } \\
\text { types }\end{array}$ & $\begin{array}{l}\text { Predominant } \\
\text { flower source } \\
\text { according to } \\
\text { beekeepers }\end{array}$ & $\begin{array}{l}\text { Predominant } \\
\text { pollen class } \\
(>45 \%)\end{array}$ & $\begin{array}{l}\text { Secondary } \\
\text { pollen class } \\
(16-45 \%)\end{array}$ & $\begin{array}{l}\text { Important minor }(3-15 \%) \\
\text { and minor pollen }(<3 \%) \\
\text { classes }\end{array}$ & $\begin{array}{l}\text { Predominant } \\
\text { flower source } \\
\text { palynologically } \\
\text { indicated }\end{array}$ \\
\hline $\begin{array}{c}\text { BL1 } \\
(n=14)\end{array}$ & $\begin{array}{l}\text { eucalyptus } \\
\text { (Eucalyptus spp., } \\
\text { Myrtaceae) }\end{array}$ & - & $\begin{array}{c}\text { Eucalyptus } \\
(38,2 \%) \text { and } \\
\text { Myrcia } 2(29.6 \%)\end{array}$ & $\begin{array}{l}\text { Borreria verticillata, Cecropia } \\
\text { (14.8\%), Cuphea flava, } \\
\text { Desmodium, Euterpe, Mikania, } \\
\text { Mimosa caesalpiniifolia, M. } \\
\text { pudica, Myrcia 1, Richardia, } \\
\text { Simira, and Vernonia }\end{array}$ & $\begin{array}{l}\text { Eucalyptus sp. } \\
\text { and Myrcia sp. }\end{array}$ \\
\hline $\begin{array}{c}\text { EU1 } \\
(n=10)\end{array}$ & $\begin{array}{l}\text { eucalyptus } \\
\text { (Eucalyptus spp., } \\
\text { Myrtaceae) }\end{array}$ & - & $\begin{array}{l}\text { Cecropia (16.8\%), } \\
\text { Eucalyptus } \\
(35.8 \%)\end{array}$ & $\begin{array}{c}\text { Borreria verticillata, } \\
\text { Bougainvillea (13.6\%), } \\
\text { Desmodium, Brosimum, } \\
\text { Mikania, Myrcia 1, Piper and } \\
\text { Vernonia }\end{array}$ & Eucalyptus spp. \\
\hline $\begin{array}{c}\text { GU1 } \\
(n=9)\end{array}$ & $\begin{array}{l}\text { eucalyptus } \\
\text { (Eucalyptus spp., } \\
\text { Myrtaceae) }\end{array}$ & $\begin{array}{c}\text { Mimosa pudica } \\
(86.6 \%)\end{array}$ & - & $\begin{array}{c}\text { Attalea, Cecropia, Elaeis } \\
\text { guineensis, Eucalyptus, } \\
\text { Miconia, Myrcia 1, Poaceae } \\
\text { type, Vernonia }\end{array}$ & $\begin{array}{l}\text { No predominant } \\
\text { flower source }\end{array}$ \\
\hline $\begin{array}{c}\text { GU2 } \\
(n=7)\end{array}$ & $\begin{array}{c}\text { velame } \\
\text { (Croton spp., } \\
\text { Euphorbiaceae) }\end{array}$ & $\begin{array}{c}\text { Mimosa pudica } \\
(50.0 \%)\end{array}$ & $\begin{array}{l}\text { Eucalyptus } \\
\quad(35.6 \%)\end{array}$ & $\begin{array}{c}\text { Brosimum (11.4\%), Cecropia, } \\
\text { Elaeis guineensis, Myrcia } 1 \\
\text { and Vernonia }\end{array}$ & Eucalyptus sp. \\
\hline $\begin{array}{c}\text { GU3 } \\
(n=8)\end{array}$ & $\begin{array}{c}\text { velame } \\
\text { (Croton spp., } \\
\text { Euphorbiaceae) }\end{array}$ & - & $\begin{array}{c}\text { Mimosa pudica } \\
\text { (21.6\%) and } \\
\text { Solanum } 1 \\
(28.3 \%)\end{array}$ & $\begin{array}{c}\text { Brosimum, Cecropia, } \\
\text { Eucalyptus, Mikania, Poaceae } \\
\text { type }(15 \%) \text { and Vernonia }\end{array}$ & $\begin{array}{l}\text { No predominant } \\
\text { flower source }\end{array}$ \\
\hline $\begin{array}{c}\text { GU4 } \\
(n=9)\end{array}$ & $\begin{array}{l}\text { velame } \\
\text { (Croton spp., } \\
\text { Euphorbiaceae) }\end{array}$ & $\begin{array}{c}\text { Mimosa pudica } \\
(48.6 \%)\end{array}$ & $\begin{array}{l}\text { Eucalyptus } \\
(30.7 \%)\end{array}$ & $\begin{array}{c}\text { Cecropia, Cuphea, Lamiaceae } \\
\text { type, Mimosa caesalpiniifolia, } \\
\text { Myrcia 1, Solanum 1, and } \\
\text { Vernonia }\end{array}$ & Eucalyptus sp. \\
\hline $\begin{array}{l}\text { GU5 } \\
(n=5)\end{array}$ & $\begin{array}{c}\text { velame } \\
\text { (Croton spp., } \\
\text { Euphorbiaceae) }\end{array}$ & - & $\begin{array}{c}\text { Mimosa pudica } \\
\text { (32\%) and } \\
\text { Solanum } 1 \\
(28.3 \%)\end{array}$ & $\begin{array}{l}\text { Brosimum, Cecropia and } \\
\text { Poaceae type (15.2\%) }\end{array}$ & $\begin{array}{l}\text { No predominant } \\
\text { flower source }\end{array}$ \\
\hline $\begin{array}{c}\text { IT1 } \\
(n=13)\end{array}$ & $\begin{array}{l}\text { eucalyptus } \\
\text { (Eucalyptus spp., } \\
\text { Myrtaceae) }\end{array}$ & $\begin{array}{l}\text { Eucalyptus } \\
\quad(79.8 \%)\end{array}$ & - & $\begin{array}{c}\text { Acacia, Borreria } \\
\text { verticillata, Cordia, Elaeis } \\
\text { guineensis, Hyptis, Mimosa } \\
\text { caesalpiniifolia, M. pudica } \\
\text { (10.8\%), Mormodica, Myrcia 1, } \\
\text { Poaceae type, Solanum } 1 \text { and } \\
\text { Vernonia }\end{array}$ & Eucalyptus spp. \\
\hline $\begin{array}{c}\text { IT2 } \\
(n=6)\end{array}$ & $\begin{array}{l}\text { Brazilian } \\
\text { peppertree } \\
\text { (Schinus } \\
\text { terebinthifolia } \\
\text { Raddi, } \\
\text { Anacardiaceae) }\end{array}$ & $\begin{array}{l}\text { Eucalyptus } \\
\quad(53.6 \%)\end{array}$ & $\begin{array}{c}\text { Mimosa pudica } \\
(38.2 \%)\end{array}$ & $\begin{array}{c}\text { Borreria verticillata, Mimosa } \\
\text { caesalpiniifolia, Myrcia } 3 \text { and } \\
\text { Solanum } 1\end{array}$ & Eucalyptus spp. \\
\hline $\begin{array}{c}\text { PS1 } \\
(n=10)\end{array}$ & $\begin{array}{l}\text { eucalyptus } \\
\text { (Eucalyptus spp., } \\
\text { Myrtaceae) }\end{array}$ & $\begin{array}{c}\text { Eucalyptus } \\
(79.2 \%)\end{array}$ & - & $\begin{array}{c}\text { Borreria verticillata, } \\
\text { Brosimum (12\%), Cecropia, } \\
\text { Mimosa pudica, Pilosocereus, } \\
\text { Poaceae type, Senegalia, } \\
\text { Solanum } 2 \text { and Vernonia }\end{array}$ & Eucalyptus spp. \\
\hline
\end{tabular}


pollen type Eucalyptus predominated in the IT1 (79.8\%) and IT2 (53.6\%) pollen spectra. The IT2 had the Mimosa pudica (38.2\%) as secondary pollen. Both honey samples were palynologically classified as having a predominant Eucalyptus spp. (Myrtaceae) flower source (Table II).

The beekeepers previously indicated eucalyptus (Eucalyptus spp., Myrtaceae) as the predominant flower source for the honey from Porto Seguro. We found Eucalyptus (79,2\%) pollen type as predominant pollen. Therefore, the predominant Eucalyptus spp. (Myrtaceae) flower source palynologically characterizes the sample (Table II).

\section{DISCUSSION}

The pollen spectrum of some honey samples from the Discovery Coast of Bahia differs from the predominant flower sources previously indicated by regional beekeepers. The beekeepers' empirical knowledge provides substantial information for understanding the pollen spectra of bee products. However, following the bees foraging around apiaries or observing the flowering plant species in the surroundings - how predominant flower source of honey is commonly indicated by beekeepers is insufficient to reveal the range of floral sources visited by bees throughout a period. Combining the data provided by beekeepers with those derived from the palynological analysis provides a more reliable identification of the floral source of bee products.

Three predominant flower sources had been indicated by local beekeepers for the honey samples: Brazilian peppertree (Schinus terebinthifolia), eucalyptus (Eucalyptus spp.) and velame (Croton spp.). However, only the Eucalyptus pollen type figured in the honeys. S. terebinthifolia, the Brazilian peppertree
- locally known as aroeira, aroeira-da-praia and pimenta-rosa - is widely distributed in Brazil, in different phytogeographic domains (Flora do Brasil 2020), and commonly found in Brazilian monofloral and plurifloral honeys (Barth 1990, Souza et al. 2019). Similarly, Croton was absent in the pollen spectra, although the genus has attractive species for bees (Borges et al. 2014, Santos et al. 2018, Souza et al. 2019).

All pollen types identified in honeys from the Discovery Coast figure in an exhaustive list compiled by Souza et al. (2019). This compendium aggregates pollen types reported for Brazilian bee products by melissopalynological studies. In our analysis, the predominant and secondary pollen types found in the honeys were Cecropia, Eucalyptus, Mimosa pudica, Myrcia 2, Solanum 1 , and Vernonia. Among them, the Eucalyptus types stand out because eucalyptus plantations prevail in the southern Bahia scenario. In according to Marchini et al. (2003), eucalyptus is one of the best and most abundant nectar suppliers for bees. We obtained the honey samples from municipalities that house eucalyptus plantations for cellulose production. The main company maintains a cooperative agreement with beekeeper associations in the region to provide sites - apicultural pastures for honey production (Veracel 2019). Therefore, beekeepers already expect eucalyptus as the predominant flower source for honeys in some apicultural seasons.

The occurrence of Myrtaceae pollen grains, especially from Eucalyptus spp., in honey samples from Apis mellifera bees is well known in Brazil, such as in studies by Aires \& Freitas (2001) in Ceará, Bastos et al. (2003) in Minas Gerais, and Borsato et al. (2014) in Paraná. They highlight the nectariferous and polleniferous potential of Eucalyptus spp. to compound the honeys produced in those states. Oliveira \& Santos (2014) reported that pollen types related 
to commercial crops, such as eucalyptus, were found at a high frequency in honeys produced in the extreme south of Bahia. These authors also highlighted the Myrcia sp. pollen type as a secondary pollen in other regions of Bahia. Similarly, we noticed that Myrcia pollen types are frequent in honeys from the Discovery Coast region, although in a lower percentage than Eucalyptus. Species- and even genus-level identification of eucalyptus and other Myrtaceae pollen types is often difficult (Sniderman et al. 2018). As the south of Bahia still lacks a comprehensive floristic list, we identified most of the pollen types at a genus-level.

Pollen types related to mostly polliniferous species, such as Cecropia, Mimosa pudica and Solanum 1, figured as predominant or secondary pollen in seven samples. This is common for Brazilian honeys (Barth 2004, Souza et al. 2019). For example, pollen types associated with Cecropia Loefl species are reported for the pollen spectrum of dehydrated pollen (Dórea et al. 2010), propolis (Avelino \& Santos 2018), and honey (Moreti et al. 2000, Luz et al. 2007, Sodré et al. 2007, Silva \& Santos 2014, Nascimento et al. 2015). Cecropia is a typical pioneer tree generally recognized as anemophilous, although it also undergoes entomophily (Monjoin \& Wandji 2018). The anemophilous pollen is easily dispersed by the wind, and may occasionally enter into the composition of honey. The Cecropia pollen type was also recorded as a predominant pollen and a secondary pollen in honeys from the Southern Coast of Bahia (Oliveira \& Santos 2014), and in the Discovery Coast (Bandeira \& Novais 2020).

Melissopalynological studies in different countries (Ramírez-Arriaga et al. 2011, Dobre et al. 2013, Ponnuchamy 2014), including Brazil (Barth 2004, Freitas \& Novais 2014, Souza et al. 2019), report the pollen type related to Mimosa pudica (Fabaceae), an invasive plant species that colonize degraded areas (Queiroz 2009). In
Bahia, Fabaceae species contribute significantly to the constitution of honey (Oliveira et al. 2010, Novais et al. 2009, Nascimento et al. 2015, Oliveira \& Santos 2014, Bandeira \& Novais 2020). Many Fabaceae species have high apicultural potential due to their widespread distribution across many geographical regions, and their supply of floral resources for bees (Carvalho \& Marchini 1999, Carvalho et al. 2001, Lorenzon et al. 2003).

Finally, we highlight that the plantation and deforestation corridors on the Bahian Discovery Coast strongly mark the anthropic action in the areas where the honeys come from. This explains why the pollen spectra reveals many pollen types related to cultivated or widely distributed plant species, commonly found in anthropized areas. We confirmed the predominant botanical origin (Eucalyptus spp.) indicated by beekeepers for $40 \%$ of the honey samples from the Discovery Coast investigated in the present study. Similarly, Horn (1997) and Borges et al. (2014) studied monofloral honeys, and also noticed a discrepancy between the predominant flower source indicated by the seller or beekeeper and that established through pollen analysis. This reinforces how palynological studies can validate and complement the data obtained by beekeepers in the apiary's daily routine.

\section{Acknowledgments}

We thank to the beekeepers for providing the honey samples, and the coordinators of the Plant Micromorphology Laboratory at the Universidade Estadual de Feira de Santana (UEFS), especially Dr PP Oliveira, for methodological advices. We are also indebted to the Fundação de Amparo à Pesquisa do Estado da Bahia (FAPESB) for a MSc grant to MSFB (BOL2041/2017) and for financial supporting this research project (APP011/2016), and to the Universidade Federal do Sul da Bahia and the Instituto Federal da Bahia (IFBA) for logistical support to field work. 


\section{REFERENCES}

AIRES ERB \& FREITAS BM. 2001. Caracterização palinológica de algumas amostras de mel do estado do Ceará. Rev Ciênc Agron 32(1/2): 22-27.

ALMEIDA-MURADIAN LB, SOUZA RJ, BARTH OM \& GALLMANN P. 2014. Preliminary data on Brazilian monofloral honey from the northeast region using FT-IR ATR spectroscopic, palynological, and color analysis. Quím Nova 37: 716-719.

ANDRADE PB, AMARAL MT, ISABEL P, CARVALHO JCMF, SCABRA R \& CUNHA AP. 1999. Physicochemical atributes and pollen spectrum of Portuguese Heather honeys. Food Chem 66: 503-510.

AVELINO LO \& SANTOS FAR. 2018. The presence of Fabaceae in the pollen profile of propolis produced in northeastern Brazil. Acta Bot Bras 32(4): 602-614.

BANDEIRA MSF \& NOVAIS JS. 2020. Melissopalynological characterization of honeys from the Discovery Coast, Brazil. Palynology 44(3): 539-550.

BARTH OM. 1990. Pollen in monofloral honeys from Brazil. J Apic Res 29: 89-94.

BARTH OM. 2004. Melissopalynology in Brazil: a review of pollen analysis of honeys, propolis and pollen loads of bees. Sci Agric 61(3): 342-350.

BASTOS EMAF, SILVEIRA EM \& SOARES AEE. 2003. Espectro polínico do mel produzido em áreas de cerrado do Estado de Minas Gerais (Brasil). Braz J Biol 63(4): 599-615.

BELAY A, HAKI GD, BIRRINGER M, IRRINGER D, BORCK H, ADDI A, BAYE K \& MELAKU S. 2017. Rheology and botanical origin of Ethiopian monofloral honey, Food Sci Technol 75: 393-401.

BORGES RLB, JESUS MC, CAMARGO RCR \& SANTOS FAR. 2014. Pollen content of marmeleiro (Croton spp., Euphorbiaceae) honey from Piauí State, Brazil. Palynology 38(2): 179-194.

BORGES RLB, LIMA LCL, OLIVEIRA PP, SILVA FHM, NOVAIS JS, DÓREA MC \& SANTOS FAR. 2006. O pólen no mel do semiárido brasileiro. In: SANTOS FAR (Ed), Apium Plantae. Recife: IMSEAR, p. 103-118.

BORSATO DM ET AL. 2014. Topical anti-inflammatory activity of a monofloral honey of Mimosa scabrella provided by Melipona marginata during winter in southern Brazil. J Med Food 17(7): 817-825.

CARVALHO CAL \& MARCHINI LC. 1999. Plantas visitadas por Apis mellifera $L$. no vale do rio Paraguaçu, Município de Castro Alves, Bahia. Rev Bras Bot 22(2): 333-338.
CARVALHO CAL, MORETI ACCC, MARCHINI LC, ALVES RMO \& OLIVEIRA PCF. 2001. Pollen spectrum of samples of uruçu bee (Melipona scutellaris Latreille, 1811) honey. Rev Brasil Biol 61(1): 63-67.

CIAPPINI M, VITELLESCHI M \& CALVIÑO A. 2016. ChemometricS classification of argentine clover and eucalyptus honeys according to palynological, physicochemical, and sensory properties. Int J Food Prop 19: 111-123.

DOBRE I, PETRU A, ESCUREDO O \& SEIJO CM. 2013. Palynological evaluation of selected honeys from Romania. Grana 52(2): 113-121.

DÓREA MC, AGUIAR CML, FIGUEROA LER, LIMA LCL \& SANTOS FAR. 2010. Residual pollen in nests of Centris analis (Hymenoptera, Apidae, Centridini) in an area of caatinga vegetation from Brazil. Oecol Austr 14(01): 232-237.

ERDTMAN G. 1960. The acetolysis method. A revised description. Sv Bot Tidsk 39: 561-564.

FLORA DO BRASIL. 2020. Flora do Brasil 2020 em construção. Jardim Botânico do Rio de Janeiro. http://floradobrasil. jbrj.gov.br/reflora/floradobrasil/FB17544. 20 abril. 2020.

FREITAS WAT \& NOVAIS JS. 2014. Melissopalynology in the Brazilian Amazon: a data bank of pollen types cited in the literature. Bol Asoc Lat Paleobot Palinol 14: 103-136.

HORN H. 1997. Méis brasileiros: resultados de análises físico-químicas e palinológicas. Mensagem Doce 40: 10-16.

IBGE - INSTITUTO BRASILEIRO DE GEOGRAFIA E ESTATÍSTICA (BR). 2016. Produção da Pecuária Municipal. 2016. Disponível em: https://biblioteca.ibge.gov.br/visualizacao/ periodicos/84/ppm_2016_v44_br.pdf. Acesso em: 05 mar. 2019.

JONES GD \& BRYANT JR VM. 1996. Melissopalynology. In JANSONIUS J \& MCGREGOR DC (Eds), Palynology: principles and applications. Dallas: American Association of Stratigraphic Palynologists Foundation, p. 933-938.

KADRI SM, ZALUSKI R, LIMA GPP, MAZZAFERA P \& ORSI RO. 2016. Characterization of Coffea arabica monofloral honey from Espírito Santo. Food Chem 203: 252-257.

LORENTE FL, BUSO JR AA, OLIVEIRA PE \& PESSENDA LCR. 2017. Atlas palinológico: Laboratório 14C - Cena/USP. Piracicaba: FEALQ.

LORENZON MCA, ATRAGNOLO CAR \& SCHOEREDER JH. 2003. Flora visitada pelas abelhas eussociais (Hymenoptera, Apidae) na serra da Capivara, em catinga do Sul do Piauí. Neotrop Entomol 32(1): 27-36.

LOUVEAUX J, MAURIZIO A \& VORWOHL G. 1978. Methods of melissopalynology. Bee World 59(4): 139-157. 
LUZ CFP, THOMÉ ML \& BARTH OM. 2007. Recursos tróficos de Apis mellifera L. (Hymenoptera, Apidae) na região do Morro Azul do Tinguá, Estado do Rio de Janeiro. Rev Bras Bot 30: 29-36.

MAKHLOUFI C, KERKVLIET J \& SCHWEITZER P. 2015. Characterisation of some monofloral Algerian honeys by pollen analysis. Grana 54(2): 156-166.

MARCHINI LC, MORETI ACCC \& SILVEIRA NETO S. 2003. Características físico-químicas de amostras de mel e desenvolvimento de enxames de Apis mellifera L., 1758 (Hymenoptera, Apidae), em cinco diferentes espécies de eucaliptos. B CEPPA 21(1): 193-206.

MOAR NT. 1985. Pollen analysis of New Zealand honey. New Zeal J Agr Res 28: 39-70.

MOLAN P. 1998. The limitations of the methods of identifying the floral source of honeys. Bee World 79(2): 59-68.

MONJOIN T \& WANDJI RT. 2018. Pollination and dissemination in the genus Cecropia: contrasts between different species. Master II EFT 2017/2018. http://www.ecofog. gf/IMG/pdf/bibliographic_synthesis_ruth_tchana_ thomas_monjoin_master_2_bioget_cecropia.pdf $20 \mathrm{Apr}$ 2020.

MORETI ACC, CARVALHO CAL, MARCHINI LC \& OLIVEIRA PCF. 2000. Espectro polínico de amostras de mel de Apis mellifera L., coletadas na Bahia. Bragantia 59(1): 1-6.

NASCIMENTO AS, CARVALHO CAL \& SODRÉ GS. 2015. The pollen spectrum of Apis mellifera honey from Reconcavo of Bahia, Brazil. JSRR 6(6): 426-438.

NOVAIS JS, ARAÚJO VLR, SILVEIRA AS \& BANDEIRA MSF. 2018. palinoFLORAS: uma palinoteca vinculada a um jardim botânico no sul da Bahia, Brasil. Paubrasilia 1(1): 20-24.

NOVAIS JS, LIMA LCL \& SANTOS FAR. 2009. Botanical affinity of pollen harvested by Apis mellifera $\mathrm{L}$. in a semi-arid area from Bahia, Brazil. Grana 48(3): 224-234.

OLIVEIRA PP \& SANTOS FAR. 2014. Prospecção palinológica em méis da Bahia. Feira de Santana: PrintMídia.

OLIVEIRA PP, VAN DEN BERG C \& SANTOS FAR. 2010. Pollen analysis of honeys from Caatinga vegetation of the state of Bahia, Brazil. Grana 49(1): 66-75.

PONNUCHAMY R, BONHOMME V, PRASAD S, DAS LIPI, PATEL P, GAUCHEREL C, PRAGASAN A \& ANUPAMA K. 2014. Honey pollen: using melissopalynology to understand foraging preferences of bees in tropical South India. PLOS ONE 9(7).

QUEIROZ LP. 2009. Leguminosas da Caatinga. Feira de Santana: Royal Botanic Gardens.
RAMALHO M, KLEINERT-GIOVANNINNI A \& IMPERATRIZ FONSECA VL. 1990. Important bee plants for stingless bees (Melipona and Trigonini) and Africanized honeybees (Apis mellifera) in Neotropical habitats: a review. Apidologie 21: 469-488.

RAMÍREZ-ARRIAGA E, NAVARRO-CALVO LA \& DÍAZ-CARBAJA E. 2011. Botanical characterisation of Mexican honeys from a subtropical region (Oaxaca) based on pollen analysis. Grana 50: 40-54.

RICCIARDELLI-D'ALBOREG. 1997. Textbook of melissopalynology. Bucharest: Apimondia Publ. H.

ROUBIK DW \& MORENO JE. 1991. Pollen and Spores of Barro Colorado. New York: Missouri Botanical Garden.

SÁNCHES AC \& LUPO LC. 2017. Pollen analysis of honeys from the northwest of Argentina: province of Jujuy. Grana 56: 462-474.

SANTOS FAR, KIILL LHP, CARNEIRO-TORRES DS, LIMA LCL, SILVA TMS, NOVAIS JS, DÓREA MC, CARNEIRO CE \& CORREIA MCN. 2018. Espécies melíferas. In: CORADIN L, CAMILO J \& PAREYN FGC (Orgs), Espécies nativas da flora brasileira de valor econômico atual ou potencial - plantas para o futuro região nordeste. Brasília: MMA, p. 969-1.010.

SEIJO MC, AIRA MJ, IGLESIAS I \& JATO MV. 2015. Palynological characterization of honey from La Coruña province (NW Spain). J Apic Res 31(3-4): 149-155.

SEIJO MC, AIRA MJ \& MÉNDEZ J. 2003. Palynological differences in the pollen content of Eucalyptus honey from Australia, Portugal and Spain. Grana 42(3): 183-190.

SILVA APC \& SANTOS FAR. 2014. Pollen diversity in honey from Sergipe, Brazil. Grana 53(2): 59-170.

SILVA FHM, SANTOS FAR \& LIMA LCL. 2016. Flora polínica das caatingas: Estação Biológica de Canudos (Canudos, Bahia, Brasil). Feira de Santana: Mícron.

SNIDERMAN JMK, MATLE KA, HABERLESG CG \& CANTRILL DJ. 2018. Pollen analysis of Australian honey. PLOS ONE 13(5): e019754.

SODRÉ GS, MARCHINI LC, CARVALHO CAL \& MORETI ACCC. 2007. Análise de pólen em amostras de méis das duas principais regiões produtoras do nordeste brasileiro. An Acad Bras Cienc 79: 381-388.

SOS MATA ATLÂNTICA FOUNDATION (BR). 2017. Relatório anual de atividades 2017. https://www.sosma.org.br/wpcontent/uploads/2018/10/AF_RA_SOSMA_2017_web.pdf. 9 jan. 2019.

SOUZA RR, ABREU VHR \& NOVAIS JS. 2019. Melissopalynology in Brazil: a map of pollen types and published 
productions between 2005 and 2017. Palynology 43(4): 690-700.

VARASSIN IG, AGOSTINI K, WOLOWSKI M \& FREITAS L. 2021. Pollination systems in the Atlantic Forest: characterisation, threats, and opportunities. In MARQUES MCM \& GRELLE CEV (Eds), The Atlantic Forest: history, biodiversity, threats and opportunities of the megadiverse forest. Cham: Springer, p. 325-344.

VERACEL. 2019. Investimento social. http://www.veracel. com.br/investimento-social/. 23 fev. 2019.

\section{How to cite}

BANDEIRA MSF \& NOVAIS JS. 2021. Brazilian peppertree, eucalyptus, and velame honeys: does palynology confirm the predominant flower sources indicated by beekeepers?. An Acad Bras Cienc 93: e20200591. DOI 10.1590/0001-3765202120200591.

Manuscript received on April 20, 2020;

accepted for publication on July 21, 2021

\section{MICHELE S.F. BANDEIRA ${ }^{1,2}$}

https://orcid.org/0000-0002-6507-7610

\section{JAÍLSON S. NOVAIS ${ }^{1,3}$}

https://orcid.org/0000-0003-3080-8994

${ }^{1}$ Programa de Pós-Graduação em Ciências e Tecnologias Ambientais, Universidade Federal do Sul da Bahia, Instituto de Humanidades, Artes e Ciências Sosígenes Costa, Rod. Porto Seguro - Eunápolis, BR 367, Km 10, 45810-000 Porto Seguro, BA, Brazil
${ }^{2}$ Programa de Pós-Graduação em Ciências e Tecnologias Ambientais, Instituto Federal da Bahia, BR 367 -

Km 57,5, 45810-000 Porto Seguro, BA, Brazil

${ }^{3}$ Programa de Pós-Graduação em Sociedade, Ambiente e Qualidade de Vida, Universidade Federal do Oeste do Pará, Centro de Formação Interdisciplinar, Rua Vera Paz, s/n, Salé, 68035-110 Santarém, PA, Brazil

Correspondence to: Jaílson S. Novais

E-mail: jailson.novais@csc.ufsb.edu.br

\section{Author contributions}

Both authors conceived the main research question, designed the field and laboratorial procedures, read and approved the final text submitted for publication. MSF Bandeira collected and processed the samples, analyzed the data, and wrote the manuscript original draft. JS Novais was the academic advisor and project supervisor, acquired the research funding, supervised data collecting and analysis, revised and edited the final version of the manuscript.

(cc) BY 